
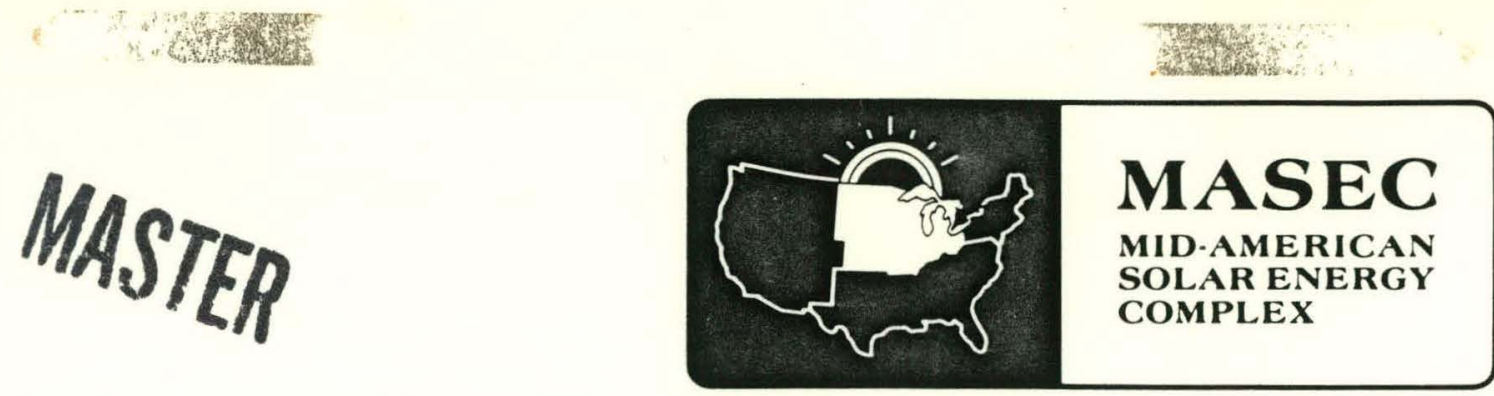

\title{
Quarterly Report of Solar Federal Buildings Program in the MASEC Region
}

Topical Report

June 1981

Prepared for

U.S. Department of Energy Under Contract No. DE-AC02-79CS30150

Submitted by Mid-American Solar Energy Complex 8140 26th Avenue South Minneapolis, Minnesota 55420 


\section{DISCLAIMER}

This report was prepared as an account of work sponsored by an agency of the United States Government. Neither the United States Government nor any agency Thereof, nor any of their employees, makes any warranty, express or implied, or assumes any legal liability or responsibility for the accuracy, completeness, or usefulness of any information, apparatus, product, or process disclosed, or represents that its use would not infringe privately owned rights. Reference herein to any specific commercial product, process, or service by trade name, trademark, manufacturer, or otherwise does not necessarily constitute or imply its endorsement, recommendation, or favoring by the United States Government or any agency thereof. The views and opinions of authors expressed herein do not necessarily state or reflect those of the United States Government or any agency thereof. 


\section{DISCLAIMER}

Portions of this document may be illegible in electronic image products. Images are produced from the best available original document. 


\title{
Quarterly Report of Solar Federal Buildings \\ Program in the MASEC Region
}

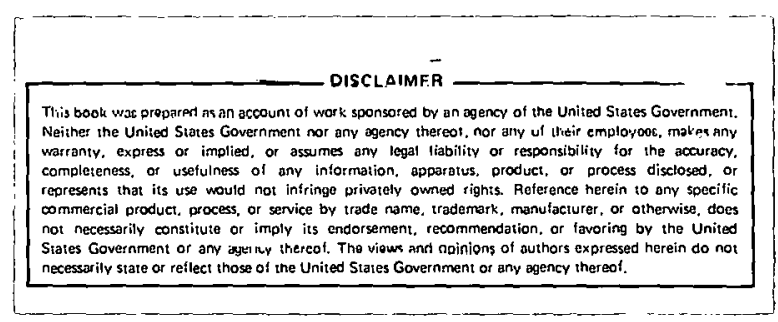

Topical Report

June 1981

\section{Mid-American Solar Energy Complex \\ 814026 th Avenue South \\ Minneapolis, Minnesota 55420}

\author{
Prepared for the \\ U.S. Department of Energy \\ Division of Conservation and Renewable Energy \\ Under Contract DE-AC02-79CS30150
}

$A-104-6$ 
This material was prepared under sponsorship of the Mid-American Solar Energy Complex (MASEC) and the U. S. Department of Energy. Neither MASEC, the United States or any agency thereof, nor any of their employees, makes any warranty, expressed or implied, or assumes any legal liability or responsibility for any third party's use or the results of such use of any designs, information, apparatus, product, or process disclosed in this material, or represents that its use by such third party would not infringe on privately owned rights. 
QUARTERLY REPORT OF SOLAR FEDERAL BUILDINGS PROGRAM IN THE MASEC REGION

\section{INTRODUCTION}

The objectives of the Solar Federal Building Program (SFBP) are to:

- encourage rapid commercialization of solar energy systems in the federal and private sector

- establish a federal leadership role in supporting the use of feasible solar products and systems

- expand the solar industry, and increase consumer experience with and

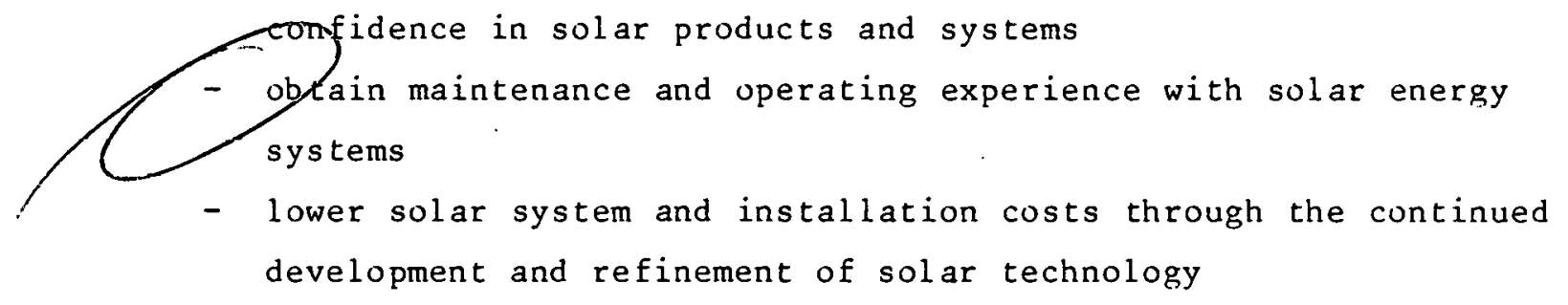

MASEC's role in the SFBP has been to provide support in marketing the program within the 12-state MASEC REGION. Specifically, MASEC is responsible for providing support in 2 major program areas: 1) Data Information Systems, which include project data, program data publications and 1 istings; 2) Market Developnent, which includes barriers, market analysis training/technical information, candidate identification and program information.

\section{MASEC SFBP Action}

MASEC staff members contacted agencies coordinating the Solar Federal Buildings Program within the 12-state MASEC region (Illinois, Indiana, Iowa, Kansas, Michigan, Minnesota, Missuuri, Nebraska, North Dakota, Ohio, South Dakota, and Wisconsin).

MASEC identified those projects where (see Attachment I)

(a) construction has been completed,

(b) projects have been cancelled,

(c) projects where solicitations for bids have been completed, and

(d) projects where bids are expected to be solicited. 
MASEC requested SFBP agencies with projects in the MASEC region to submit all information available about the projects that the agencies are coordinating. As information is received from the SFBP agencies coordinating bid solicitations, MASEC works through its outreach organizations to encourage solar contractors from the MASEC region to submit competitive bids. These organizations are State Solar offices, which are affiliated with each State Energy Agency or its equivalent, and State Solar Resource Advisory Panels which are composed of professional individuals, corporations and associations in the solar community (see Attachment II). Utilizing their communication networks, these agencies and organizations inform the solar industry of the specific SFBP projects. MASEC also provides information to the solar industry directly through special mailings.

\section{SFBP Short Course}

MASEC has also disseminated information on a SFBP Short Course that will take place in St. Paul, Minnesota, August 17-21, 1981. A letter with information about the SFBP Short Course was sent to the State Solar offices and the Solar Resource Advisory Panels (see Attachment III). Material was also sent via a special mailing to 1400 solar energy industry professionals in the MASEG region. 


\section{ILLINOIS}

\section{PROGRAM COORDINATOR}

Stanley Vachta

Dole Argonne National Labs 900 South Cass Avenue Argonne, IL 60439

(312) 972-5241
PROPOSAL \#

$(5-6028)$

Argonne
David Mead

Headquarters AAFES/ENC

P.O. Box 222305

Dallas, TX 75222

(214) 330-3801
(5-1336)

Belleville

$(5-8227)$

Batavia
Hank Hinterberger

P.O. Box 500

Batavia, It. 60510

(312) 840-3394
Bernard (Ben) La Rocca

Terry Maloy

230 South Dearborn Street

Chicago, IL 60604

(312) 353-1128

\section{PROJECT STATUS}

(IDH - EVACUATED TUBES)

They solfcited and received bids for evaporated tubes and contracting the work to be completed. Bids deadline was in May. They are waiting for the funds to be transferred from DOE before they make final award.

(DHW)

They will send out a proposal soliciting bids during week of June 22.

(Passive Solar)

Contract granted. Project is expected to be completed by August 1 and will be within budgct.

(DHh')

Soliciting proposals from $A$ and E firms to do project. Commerce Business Daily will have information around week of July 13. 


\section{PROGRAM COORDINATOR}

Bernard LaRocca/5PBI

230 South Dearborn Street

Chicago, IL 60604

(132) 353-1128
PROPOSAL \#

(5-1674)

Gary, IN

\section{PROJECT STATUS}

(DHW)

Soliciting proposals from $A$ and $E$ firms to do project - Commerce Business Daily will have information around week of July 13.

(DHW)

Soliciting proposals from $A$ and $E$ firms to do project - Commerce Business Daily will have information around week of July 13. 
PROGRAM COORDINATOR

John Flemming 1500 East Bannister Road Kansas City, MO 64131 (816) 926-5294
PROPOSAL \#|

(7-1666)

Fort Dodge
(7-1665)

Iowa. City
PROJECT STATUS

(DHW)

Design is being developed in house and will be reviewed by NASA. They expect to be soliciting bids for construction around September.

\section{(DHW)}

Design is being developed in house and will be reviewed by NASA. They expect to be soliciting bids for construction around September. 
$\underline{\text { KANSAS }}$

PROGRAM COORDINATOR

John Flemming

1500 East Bannister Road

Kansas City, MO 64131

(816) 926-5294
PROPOSAL \#

(7-4008)

Abilene

(7-4014)

Kansas City

$(7-1664)$

Leavenworth

(7-1663)

Topeka

David Mead

Headquarters AAFES/ENC

P.O. BOX 222305

Dallas, TX 75222

(214) 330-3803
$(7-1337)$

Leavenworth

(7-4018)

Paola

Archie Gatrost

601 East 12th Street

Kansas, MO 64106

(816) $374-2934$

PROJECT STATUS

(DHW) .

They will develop

the design for the project "in-house"

for NASA to review.

They expect to

solicit bids for

construction in

October.

(DHW)

NASA is reviewing

the design for the

project now. The:

anticipated solicit-

ing bids for con-

struction in August.

(DHh)

NASA is reviewing

the design for the

project now. They

anticipated solicit-

ing bids for con-

struction in August.

(DHW)

NASA is reviewing

the design for the project now. They

anticipated soliciting bids for construction in August.

(DHW)

They will be soliciting bids within a couple of weeks.

(Space and $\mathrm{H}_{2} \mathrm{O}$ heating with air collector)

They are doing the design for the project "in-house". It is nor: before DOE for final review. They expect to solicit bids by July 1. 


\section{MICHIGAN}

\section{PROGRAM COORDINATOR}

Bernard LaRocca

230 South Dearborn Street

Chicago, IL 60604

(312) 353-1128

Nick Stratton

Detroit Arsenal

Warren, MI 48090

(313) 574-5154
PROPOSAL \#

(5-1670)

Grand Rapids

$(5-1750)$

Warren

\section{PROJECT STATUS}

(DHW)

Soliciting proposals from $A$ and $E$ firms.

Commerce. Business

Daily will have info around week of July 13.

(DHW - space and $\mathrm{H}_{2} \mathrm{O}$ heating also IPM application)

Unable to contact. 


\section{MINNESOTA}

\section{PROGRAY COORDINATOR}

Bernard LaRocca

230 Dearborn Street

Chicago, IL 60604

(312) 353-1128

11

11

D. Lindroth

P.O. Box 1660

Minneapolis, MN 55111

(612) $425 \cdots 3465$
PROPOSAL \#!

(5-1671)

Bemidji

(5-1669)

Mpls.

(5-1672)

Mp 1s.

(5-4032)

Mp1s.
PROJECT STATLS

(DHW)

Soliciting proposals from $A$ and $E$ firms to do the project. Commerce Business Daily will have info around week of July 13.

(DHi)

Soliciting proposals from $A$ and $E$ firms to do the project. Commerce Business Daily will have info around week of July 13.

Canceled because of shading problems.

(Space and $\mathrm{H}_{2} \mathrm{O}$ heating with evacuated tube collectors)

Unable to contact. 
PROGRAM COORDINATOR

John Flemming

1500 East Bannister Road Kansas City, MO 64131

(816) $926-7655$
PROPOSAL \#:

(7-1662)

Hannibal

$(7-4012)$

Overland

(7-6026)

Kansas City
PROJECT STATLS

(DHW)

They are developing the design for this project "inhouse". To be reviewed by NASA. They plan to solicit bids for construction in October.

(DHW)

They are develoning the design for this project "inhouse". To be reviewed by NASA. They plan to solicit bids for construction in October.

(IPH-concentrating collectors) (Preheat 0il)

Lnable to contact.

P.0. Box 5400

(505) 264-8836 


\section{NEBRASKA}

PROGRAM COORDINATOR

John Flemming

1500 East Bannister Road Kansas City, MO 64131

(816) 926-7655
PROPOSAL \#

(7-1661)

North Platte

David Mead

Headquarters

AAFES/ENC.

P.O. Box 222305

Dallas, TX 75222

(214) $330-3830$

$(7-1342)$

Omaha
PROJECT STATLS

(DHW-space heating)

They are develop-

ing the design for

the project "in-

"house" for NASA

to review. They

plan to solicit

bids for construc-

tion in September.

(DHW)

They will send out proposals soliciting bids during

the next couple of weeks. 
PROGRAM COORDINATOR

George Fors

US Custom Service Rm 410

1.301 Constitution Avenue NW

Washington, D.C. 20227

(202) 566-5471
PROPOSAL \#

$(8-1737-38)$

Carburg

$(8-1610-11)$

Hansboro

11

11

11

"I

"1
$(8-1739-40)$

Sherwood

(8-2034)

Neche

$(8-1735-36)$

Hoonan*

(8-2035)

Hoonan

(8-2036)

Sherwood
PROJECT STATUS

Bids for design and construction of the project will be solicited in late July.

(DHW)

Bids for design and construction of the project are expected to be solicited in August .

(DHW)

Bids for design and construction of the project are expected to be solicited in late July.

(DHW)

Bids for design and construction of the project will be solicited in August.

(DHW)

Bids for design and construction of the project will be solicited in August.

(DHW)

Bids for design and construction of the project will be solicited in August.

(Space heating-flat plate collectors) 
NORTH DAKOTA (continued)

PROGRAM COORDINATOR

George Fors

"

$"$

Carl Swenson

Public Service Building

Building 41, Federal Center

Denver, CO 80225

(303) $234-2646$

$"$

Richard Simmons

P.0. Box 25287

655 Parfet Street

Denver, CO 80225

(303) $234-6450$
PROPOSAL 非

(8-1741-42)

Walhalla

(8-1372-73)

Westhope

(8-2030)

Westhope

(8-1641)

Bismarck

(8-1640)

Fargo

(8-1452-63)

Medora
PROJECT STATUS

(DHW)

Bids for design and construction of the project will be solicited in August.

(DHW)

Award for projects made

1) $\$ 5,000$

2) $\$ 4,855$

They are using evacuated tube collectors.

(DHW)

Canceled.

(DHW)

July 22 , bid opening date.

(DHW)

July $22 \mathrm{~m}$ bid opening date.

(DHW)

Have not received info. 


\section{PROGRAM COORDINATOR}

Bernard LaRocca

230 Dearborn South

Chicago, IL 60604

(312) 353-1128

"I

N.J. Pleimann

Mound Facility

Miamisburg, $\mathrm{OH}$

45342

(513) 865-3600
PROPOSAL \#\#

$(5-1667)$

Dayton

$(j-1668)$

Toledo

(5-2010)

Miamisburg

\section{PROJECT STATUS}

(DHW)

Soliciting proposals from $A$ and $E$ firms. Commerce Business Daily will have info around week of July 13.

(DIIW)

Soliciting proposals from $A$ and $E$ firms. Commerce Business Daily will have info around week of July 13.

(Space heating-flac plate collectors)

Unable to contact. 
PROGRAM COORDINATOR

Carl Swenson

Public Service Building

Building 41, Federal Center

Denver, CO 80225

(303) $234-2646$ $\underline{\text { PROPOSAL \# }}$

(8-1636)

Aberdeen

$(8-1637)$

Huron

"1

(8-1639)

Pierre

$(8-1638)$

Rapid City

\section{PROJECT STATUS}

(DHW)

July 22 , bid opening date.

(DHW)

July 14 , bid opening date.

(DHW)

July 14 , bid opening date.

(DHW)

July 14 , bid opening date.

(DHW)

Have received into.
Richard Simmons

P.0. Box 25281

655 Parfet Street Denver, CO 80255

(303) $234-6450$
(8-1441-1446)

Hot Springs

Wind Cave National Park
(8-1578-1582)

Interior Badland National Park
(DHW)

Have received info. 


\section{WISCONSIN}

\section{PROGRAM COORDINATOR}

James Lundeen

3900 South Wadsworth Blvd.

Denver, CO 80235

(303) $234-5440$

Dennis Lechniak

2000 West Pioneer Parkway

Peoria, IL 61614

(309) 671-7141

\section{PROPOSAL \#}

(5-4065)

Madison

(5-4060)

Madison

\section{PROJECT STATUS}

(Space and $\mathrm{H}_{2} \mathrm{O}$ heatingconcentrating collector) A proposal soliciting bids will be-sent out within a month.

(DHW-space and $\mathrm{H}_{2} \mathrm{O}$ ) Project is complete. 


\section{ILLINOIS}

Mr. James Hartley, Chairperson

P.O. Box 526

St. Charles, IL 60174

(312) 377-9363

\section{INDIANA}

Dr. Robert E. Henderson

Chairperson, PRPB

Executive Director

Indianapolis Center for Advanced Research

1219 West Michigan

Indianapolis, IN 46202

(317) 264-4508

IOWA

Mr. Larry Bean, Chairperson

Kirkwood Community College

6301 Kirkwood Boulevard

Cedar Rapids, IA 52406

(319) 398-5592

\section{$\underline{\text { KANSAS }}$}

Mr. Joseph 'l'. Pajor, Chaliperson

Center for Alternate Energies, Inc.

P.O. Box 1340

Dodge City, KS 67801

(316) 225-0296

\section{MICHIGAN}

Mr. Edward Kelly.

Michigan Solar Energy Association

201 East Liberty Street

Ann Arbor, MI 48104

(313) $994-5650$

Ms. Sandy Miller

Alternate Energy Industries Association

1955 Pauline Boulevard

Suite 300

Ann Arbor, MI 48103

(313) 665-5051

\section{MINNESOTA}

Mr. James P. Uttley

Metropolitan Council

300 Metro Square Building

St. Paul, MN 55114

(612) 291-6361

\section{MISSOURI}

Mr. Jordan Heiman, Chairperson

110 Stoney Side Lane

St. Louis, MO 63132

(314) 993-1302

\section{NEBRASKA}

Dr. Bing Chen, Chairperson

Associate Professor

School of Engineering Technology

University of Nebraska at Omaha

Engineering Building, Room 266

Omaha, NE 68101

(402) 554-2769

OHIO

Ms. Mary Tucker, Chairperson, PRPB

Environmental Library

5403 Elmer Drive

Toledo, $\mathrm{OH} \quad 43615$

(419) 537-0353 (work) 536-8365 (home)

SOUTH DAKOTA

Dr. Lyle Feisel, President, PRPB

Head-Department Electric Engineers South Dakota School of Mines and Technology

Rapid City, SD 57701

(605) 394-2451

\section{WISCONSIN}

Dr. Michael Ducey (President)

2253 East Washington Avenue Madison, WI 53704

(608) 249-1934

$251-4447$ 


\section{STATE SOLAR OFFICE COORDINATORS}

\section{ILLINOIS}

Mr. David Loos

Institute of Natural Resources

Alternative Energy Division

325 West Adam Street

Springfield, IL 62706

(217) 785-2766

INDI ANA

Ms. Mary Failey

Indiana Department of Commerce

Energy Group

440 North Meridian Street

Indianapolis, IN 46204

(317) 232-8940

IOWA

Mr. Phil ip Svanoe

lowa Energy Policy Council

Capitol Complex

Des Moines, IA 50319

(515) 281-8071

KANSAS

Mr. David Martin

Kansas Energy Office

$214 \mathrm{~W}$. 6th Street

Topeka, KS 66603

(913) $296-2496$ or 2915

MICHIGAN

Mr. Thomas G. Heck

Department of Commerce

P. 0. Box 30228

Lansing, MI 48909

(517) $373-6430$

\section{MINNESOTA}

Mr. John Dunlop

Minnesota Energy Agency

980 American Center Builuing

150 East Kellogg Boulevard

St. Paul, MN 55101

(6i2) $296-4737$
MI SSOURI

Mr. Richard Haist

Missouri Energy Office

P. 0. Box 176

Jefferson City, MO 65101

(314) $751-4000$

\section{NEBRASKA}

Mr. Robert Youngberg

University of Nebraska

W-l91 Nebraska Hall

Lincoln, NE 68588

(402) $472-3414$

NORTH DAKOTA

Mr. John Conrad

Energy Management \& Conservation 1533 North 12 th Street

Bismarck, ND 58501

(701) $224-2250$

OHI 0

Mr. Claude Eggelton

Ohio Department of Energy

30 East Broad Street, 34 th Floor Columbus, $\mathrm{OH} 43215$

(614) 466-8277

SOUTH DAKOTA

Mr. Verne Brakke

Office of Energy Policy

Capitol Lake Plaza

Pierre, SD 57501

(605) 773-3603

WISCONSIN

Ms. Bonnie Albright

Division of State Energy

101 S. Webster

8th Floor

Madison, WI 53702

(608) 266-980 


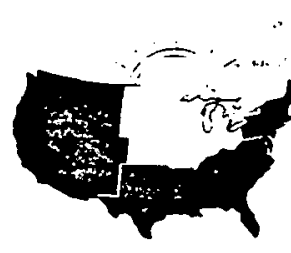

10

TO: Sso Coordinators

FROM:
Dan Cook \& Janet Deveny
DATE :

$\mathrm{RE}$ :
June 16, 1981

Solar Federal Buildings

Program - Short Course

Enclosed is a brochure about a short course on solar energy and conservation for buildings for the Solar Federal Buildings Program. The program in the MASEC Region will take place in St. Paul, Minnesota; August 17-21, 1981. The objective of the program is to encourage the use of solar heating and cooling products in new buildings as well as retrofiting old buildings. The primary audience targets architects, engineers, planners and managers with an engineering background. Please make sure this information gets to the appropriate organizations and people within your state.

$\mathrm{DCC} / \mathrm{JKD} / \mathrm{jmh}$

Enclosures 